\title{
P01.01. Neural responses to the mechanical characteristics of a spinal manipulation: effect of varying segmental contact site
}

\author{
J Pickar ${ }^{1 *}$, W Reed ${ }^{1}$, C Long ${ }^{1}$, G Kawchuk ${ }^{2}$ \\ From International Research Congress on Integrative Medicine and Health 2012 \\ Portland, Oregon, USA. 15-18 May 2012
}

\section{Purpose}

A goal of our laboratory is to identify mechanisms of action operative during the body-based practice of spinal manipulation. Spinal manipulation can be identified by a number of mechanical characteristics, including but not limited to, contact site, magnitude, rate and direction of thrusting force. Because neural mechanisms are thought to contribute to its clinical effects, we studied spinal manipulation during a series of experiments aimed at identifying mechanical characteristics that affect responses from sensory neurons innervating paraspinal tissues. Presumably, specific parameters related to these characteristics are related to successful clinical outcomes. In this study, we determined the effect of contact site on manipulation-induced neural activity of proprioceptive afferents from lumbar paraspinal muscles.

\section{Methods}

In an anesthetized cat preparation, a simulated spinal manipulation [posterior-to-anterior; thrust amplitude = $21.3 \mathrm{~N}$ ( $55 \%$ of an average cat's body weight of $3.95 \mathrm{~kg}$ ); thrust duration $=100 \mathrm{~ms}$ ] was delivered to the intact lower lumbar spine $\left(\mathrm{L}_{6}-\mathrm{S}_{1}\right.$ ) at each of 4 contact sites: $\mathrm{L}_{6}$ spinous process, left $\mathrm{L}_{6}$ mammillary process, left $\mathrm{L}_{6}$ lamina, and $\mathrm{L}_{7}$ spinous process. Electrophysiological recordings from individual muscle spindle afferents $(\mathrm{n}=16)$ innervating the $\mathrm{L}_{6}$ multifidus and longissimus muscles were obtained from $\mathrm{L}_{6}$ dorsal rootlets exposed through an $\mathrm{L}_{5}$ laminectomy. Changes in neural activity during the manipulative thrust were compared between the four contact sites.

\section{Results}

All contact sites increased mean spindle activity: $\mathrm{L}_{6}$ spinous: 85 impulses per second (imp/s) (60, 100; lower, upper $95 \% \mathrm{CI})$; $\mathrm{L}_{6}$ lamina: $104 \mathrm{imp} / \mathrm{s}(79,130)$; $\mathrm{L}_{6} \mathrm{mam}-$ millary $80 \mathrm{imp} / \mathrm{s}(55,105)$; and $\mathrm{L}_{7}$ spinous $43 \mathrm{imp} / \mathrm{s}(18$, 68). Lamina contact produced the largest increase, but only differences between the $\mathrm{L}_{7}$ spinous and each $\mathrm{L}_{6}$ contact site were statistically significant.

\section{Conclusion}

The data suggest that maximizing sensory input from segmental paraspinal tissues during a spinal manipulation requires specifically contacting that segmental level. In addition, a lamina contact may most effectively create the dynamic mechanical stimulus that evokes the sensory input.

\section{Author details}

'Palmer Center for Chiropractic Research, Davenport, USA. ${ }^{2}$ University of Alberta, Edmonton, Canada.

Published: 12 June 2012

\section{doi:10.1186/1472-6882-12-S1-P1}

Cite this article as: Pickar et al.: P01.01. Neural responses to the mechanical characteristics of a spinal manipulation: effect of varying segmental contact site. BMC Complementary and Alternative Medicine 2012 12(Suppl 1):P1.

${ }^{1}$ Palmer Center for Chiropractic Research, Davenport, USA

Full list of author information is available at the end of the article

(c) 2012 Pickar et al; licensee BioMed Central Ltd. This is an Open Access article distributed under the terms of the Creative Commons Attribution License (http://creativecommons.org/licenses/by/2.0), which permits unrestricted use, distribution, and reproduction in any medium, provided the original work is properly cited. 